UNIO - EU Law Journal. Vol. 6, No. 2, July 2020, pp 66-76.

®2020 Centre of Studies in European Union Law

School of Law - University of Minho

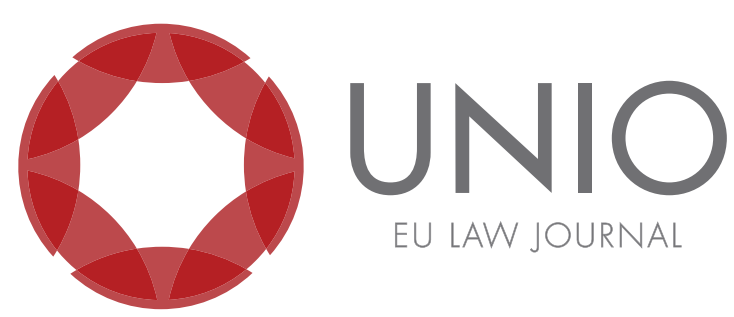

\title{
Solidarity and responsibility as a framework for the COVID-19 response in the European Union - the European Green Deal is a path?
}

\author{
Nataly Carvalho Machado*
}

ABSTRACT: Recognised as an ambitious step, the European Green Deal guides the application of European Union policies not only in the environmental field, but also in other areas that may directly or indirectly interfere with human health and environmental sustainability, with the aim of transforming climate challenges and environmental issues in applicable opportunities. With the COVID-19 crisis, major challenges have emerged and aggravated extant problems in the most varied societies. In the European Union's context, the impact of the new pandemic stood out, especially at the beginning, showing different responses by the Member States, in a disorderly and isolated way between one border and another, which highlighted when it would be placed in practice. Member States' solidarity and responsibility to work together towards an economic and social recovery plan is critical in order to keep European project alive. Therefore, in an attempt to reinforce the link between solidarity and responsibility among Member States, the European Union uses the Green Deal to respond to the crisis through a recovery that has common objectives around the sustainability and well-being of its citizens.

KEYWORDS: European Green Deal - COVID-19 - climate change - solidarity responsibility.

\footnotetext{
* Master's student in European Union Law at University of Minho.
} 


\section{Introduction}

The current scenario of environmental degradation as a talking point in the international agenda highlights our society's concerns with this issue. It is a contemporary strategic theme, ${ }^{1}$ which concerns the maintenance of a healthy and stable environment and requires understanding from a comprehensive and critical approach that promotes reflection and debate on the issue's complexity.

In this regard, the ecological crisis worsening from the second half of the $21^{\text {st }}$ century promoted the discussion about growth's ecological limits, which was stimulated by the welfare state and culminated in the systematisation of legislation regarding environmental law.

Based on this understanding, anthropic actions related to intensification of use and exhaustion of non-renewable natural resources brought a process of awareness and proliferation of the environmental theme amidst discussions on government policies. Although there were undeniable and advanced actions in this field, international environmental law, in general, lacks appropriate answers on how to engage and reasonably solve $21^{\text {st }}$ centuries' challenges related to this topic.

In this context, the coronavirus ("COVID-19") crisis arose and impacted the world, causing death, serious illness, changing life as we know it and putting every country's economy in dire straits, exposing huge social inequality around the globe. However, even with the crisis in full swing, the urgency of climate change mitigation has not disappeared and in just a few decades, the same description will fit another global crisis: climate change. ${ }^{2}$ There are several reports of reductions in pollutant emissions caused by the global shutdown due to the pandemic. Images taken via satellites and drones show us the record of abrupt drops in air and water pollution levels. ${ }^{3}$ In addition to what happens during the pandemic, the concern exists for the forthcoming postcrisis, which may show a sharp increase in the level of pollutant emissions due to the economic recovery, as has occurred in other post-crises, such as the Spanish Flu in 1918, the Great Depression in 1929 and the Financial Crisis in 2008. ${ }^{4}$

In fact, it is a reality that the coronavirus has changed and will change, drastically, people's and public authorities' priorities. Life must be protected. Until a vaccine is developed, public health control measures combined with strict social and economic measures will be implemented to handle the consequences that have already affected many countries around the globe. ${ }^{5}$

\footnotetext{
${ }^{1}$ The notion of environmental awareness appears in the $1960 \mathrm{~s}$, with the publication of the book "Silent Spring", by Rachel Carson, and its consequent expansion in the following decade, with the advent of the United Nations Conference on the Human Environment, held in Stockholm, in the year 1972. Further information available at Eliza Griswold, "How 'Silent Spring' ignited the environmental movement”, The New York Times Magazine, September 2012, https://www.nytimes.com/2012/09/23/ magazine/how-silent-spring-ignited-the-environmental-movement.html, accessed July 30, 2020.

${ }^{2}$ Information available at: https://www.gatesnotes.com/Energy/Climate-and-COVID-19, accessed July 27, 2020.

${ }^{3}$ Information available at: https://www.esa.int/ESA_Multimedia/Images/2020/04/Deserted_Venetian_lagoon; https://www.theguardian.com/environment/2020/mar/01/dramatic-fall-in-china-pollution-levels-partly-related-to-coronavirus; https://www.cnbc.com/2020/03/23/coronovirus-impact-satellites-show-world-cities-after-outbreak.html; https://www.cnbc.com/2020/03/18/ photos-water-in-venice-italys-canals-clear-amid-covid-19-lockdown.html, accessed July 27, 2020.

${ }^{4}$ João Francisco Gomes, "Não, a pandemia não é boa para o ambiente. Mas pode deixar pistas para um futuro sustentável”, Observador, April 01, 2020, https:/ /observador.pt/especiais/nao-a-pandemia-nao-eboa-para-o-ambiente-mas-pode-deixar-pistas-para-um-futuro-sustentavel/, accessed July 30, 2020.

${ }^{5}$ Nataly Machado, “Thinking about the post-COVID-19 world is putting the European Green Deal
} 
It is worth mentioning that before the health crisis due to COVID-19 and its effects spread around the world (which is most definitely a priority at this very moment), the climate and environmental crisis was on the agenda of economic reconstruction, hence why the European Parliament urged the European Commission about a climate and environmental emergency at European and global levels, and that it was a still deep and urgent matter through a Resolution dated November 28, $2019 .^{6 / 7}$

In the European Union (EU), it is no different. The COVID-19 crisis presents Europe with a challenge of historic proportions. As the Member States strive to gradually resume their economic and social recovery, they do it in such way as to avoid the idea of continuous growth at any cost tied to polluting technologies, but take as premise human needs, respecting Earth's limited resources, in line with a Green Pact and connected to new technologies.

This ambitious pact already exists and is the European Green Deal. ${ }^{8}$ A promising response to climate and environmental emergencies, the Pact was launched by a Communication from the European Commission, in December 2019, defining a plan of 50 common and transversal actions to all European policies, in order to allow the EU achieve carbon neutrality by 2050 and focus economic policy around the sustainability and well-being of its citizens.

\section{The European Green Deal and the Recovery Plan for Europe}

The European Green Deal is the EU's ambitious step towards recovery that specifies its earlier commitments ${ }^{9}$ proposed by the European Commission, ${ }^{10}$ that in its essence, brings a roadmap on how to make the EU's economy more sustainable with the goal of transforming climate and environmental challenges into opportunities applicable across all European policies ensuring a fair and inclusive transition for all Member States, "that aims to transform the EU into a fair and prosperous society, with a modern, resource-efficient and competitive economy where there are no net emissions of greenhouse gases in 2050 and where economic growth is decoupled from resource use". ${ }^{11}$

\footnotetext{
into practice: this is the time for the European Union to respond in line with 'green"', Union EU Law Journal Blog, June 16, 2020, https://officialblogofunio.com/category/news/.

${ }^{6}$ Information available at: https://oeil.secure.europarl.europa.eu/oeil/popups/summary.do?id=1600739\&$\mathrm{t}=\mathrm{d} \& \mathrm{l}=\mathrm{en}$ and https://www.europarl.europa.eu/news/en/press-room/20191121IPR67110/the-european-parliament-declares-climate-emergency. For further development about the motions for a resolution, see https://oeil.secure.europarl.europa.eu/oeil/popups/ficheprocedure.do?lang=en\&reference $=2019 / 2930(\mathrm{RSP})$, accessed July 30, 2020.

${ }^{7}$ Nataly Machado, "Thinking about the post-COVID-19”.

${ }^{8}$ For further development, see European Commission, Communication from the Commission to the European Parliament, the European Council, the Council, the European Economic and Social Committee And The Committee of the Regions the European Green Deal, Brussels, 11.12.2019, COM/2019/640 final.

${ }^{9}$ Initially made under the Paris Agreement: the first-ever universal, legally binding global climate change agreement, adopted at the Paris climate conference (COP21) in December 2015. Further information available at: https://ec.europa.eu/clima/policies/international/negotiations/paris_en.

${ }^{10}$ The Green Deal Communication sets the path for action in the months and years ahead. Information available at: https:/ / eur-lex.europa.eu/legal-content/EN/TXT/?qid=1596443911913\&uri=CELEX:52019DC0640\#document2, accessed July 27, 2020.

${ }^{11}$ Information available at: https://eur-lex.europa.eu/legal-content/PT-EN/TXT/?uri=CELEX:52019DC0640\&from=PT, accessed July 27, 2020.
} 
The Green Deal's goal is for growth to be inclusive within a sustainable model, collectively mobilising European industry for a circular and clean economy, with the implementation of adapting mechanisms to the aforementioned transition that brakes, or rather, neutralises the risk of carbon emissions from exceeding the EU Emissions Trading System. ${ }^{12}$ By doing so, it would ensure success of Union's efforts regarding its desired climate objectives not only at European level, but at the global level, in its leading role in the field of climate and global action.

Given the transversality brought about by the Green Deal, as it proposes to accelerate and support a green and fair transition in all sectors, the EU strategy revolves around growth that aims "to transform the EU into a fair and prosperous society, with a modern, resource-efficient and competitive economy", ${ }^{13}$ with the perspective of ensuring incentives aimed at adapting to climate change, in a continuous drive of public and private investments, and the inclusion of solutions based on nature, "ensuring that no one is left behind". ${ }^{14}$

To ensure that this transition is fair and effective, the Commission has set clear conditions to provide predictability to investments by funding all EU programs for climate mainstreaming, not to mention other revenue streams. In addition, the European Commission's proposal includes support for technical assistance and advisory services meant to put said projects into practice. In other words, the Green Deal proposal sets a fair environment for all Member States at the European and national levels. ${ }^{15}$

In this context, the Green Deal also aims to put people first, and pay attention to the region's industries and workers who will face the greatest challenges, transforming the EU's economy and society and putting it on a more sustainable path. Nevertheless, it will require an upfront investment with public investment and increased efforts to direct private capital towards climate and environmental action, while avoiding lock-in into unsustainable practices. This challenge, certainly, will not be achieved by Europe acting alone, because climate change is a global phenomenon, and it is not limited by national borders.

Therefore, the proposed change is refreshing and brings with it a proposal for a European Climate Law, ${ }^{16}$ with the legal basis on Articles 191 to 193 of the Treaty on the Functioning of the European Union (TFEU), to confirm and specify EU competencies in the area of climate change, and that also, plans to guarantee a neutral climate impact by $2050 .{ }^{17}$ That is to say that this body of law means to set out a ruling to all European Institutions and Member States to take appropriate actions

\footnotetext{
${ }^{12}$ The EU emissions trading system (EU ETS) is a cornerstone of the EU's policy to combat climate change and its key tool for reducing greenhouse gas emissions cost-effectively. It is the world's first major carbon market and remains the biggest one. In: https://ec.europa.eu/clima/policies/ets_en, accessed August 20, 2020.

${ }^{13}$ For further development, see European Commission, Communication from the Commission to the European Parliament, the European Council, the Council, the European Economic and Social Committee and the Committee of the Regions the European Green Deal, Brussels, 11.12.2019, $\mathrm{COM} / 2019 / 640$ final.

${ }^{14}$ For further development, see COM/2019/640 final.

${ }^{15}$ Nataly Machado, "Thinking about the post-COVID-19".

${ }^{16}$ For further development, see European Commission, Proposal for a Regulation of the European Parliament and of the Council establishing the framework for achieving climate neutrality and amending Regulation (EU) 2018/1999 (European Climate Law), Brussels, 4.3.2020, COM(2020) 80 final.

${ }_{17}$ Information available at: https://eur-lex.europa.eu/legal-content/PT-EN/TXT/?uri=CELEX:52020PC0080\&from=EN, accessed August 05, 2020.
} 
on national and cross-border levels to achieve certain binding goals regarding net-zero greenhouse gas emissions by 2050 and being the world's first climate neutral continent by the same date. It is clear, however, that this project no longer has the same socioeconomic background as when it was announced, as we are experiencing a new crisis. And worse: it adds up to the environmental crisis, which is still urgent.

The fact is that in the same way that the Green Deal is the result of a collective political understanding, in which European citizens understand that actions must be taken in favor of the climate emergency, the time to put into practice the ecological transition proposed by the Green Deal is now, united in the collective and solidarity European effort, in the post-pandemic socioeconomic recovery.

Efforts in favor of the Green Deal can already be seen in a petition addressed to the European Commission, under the name "European Alliance for a Green Recovery", 18 and signed by Member States and various sectors of civil society, ${ }^{19}$ so that economic recovery, once the COVID-19 pandemic is overcome or not - because we may have to live with this virus -, takes place under the "green pact" script, as a strategic pillar for the EU's economy.

In particular, the Commission presented a specific Recovery effort, Next Generation EU, combining the future Multiannual Financial Framework (MFF), approved by European leaders and will be rolled out under three pillars: green, digital and resilient Europe. $^{20}$ They reached an agreement, in July 21, 2020, on a massive joint recovery package - $€ 750$ billion - to respond to the coronavirus pandemic, ${ }^{21}$ as to assure a fair, inclusive, equitable and sustainable transition for all Member States and to mitigate socioeconomic damages.

In this way, the European Commission recently issued animportant Communication ${ }^{22}$ about an EU Strategy for Energy System Integration for recovery and for climate neutrality that proposes concrete policy and legislative measures at EU level to gradually shape a new integrated system, transforming the energy system while respecting each Member State's starting point. There is serious commitment from European institutions to provide and to ensure the deployment of energy efficiency technology rapidly and at large scale. Hence, the energy system is crucial to deliver on these goals, with the parallel Communication 'A hydrogen strategy for a climate-neutral Europe,"3 "is vital for shaping Europe's global leadership in clean energy technologies, by leveraging Europe's existing strengths - an

\footnotetext{
${ }^{18}$ Information available at: https:/ /www.impel.eu/alliance-appeal-for-green-recovery-from-covic-19pandemic/, accessed August 03, 2020.

${ }_{19}$ Information available at: https://www.euractiv.com/section/energy-environment/news/francegermany-join-group-of-10-eu-countries-calling-for-green-recovery/, accessed August 03, 2020.

${ }^{20}$ Next Generation EU of $€ 750$ billion as well as targeted reinforcements to the long-term EU budget for 2021-2027 will bring the total financial firepower of the EU budget to $€ 1.85$ trillion, information available at: https://ec.europa.eu/info/sites/info/files/factsheet_1_en.pdf. For further development, see European Commission, Communication from the Commission to the European Parliament, the European Council, the Council, the European Economic and Social Committe and the Committee of the Regions Europe's moment: Repair and Prepare for the Next Generation, Brussels, 27.5.2020, COM(2020) 456 final.

21 Information available at: https://www.consilium.europa.eu//media/45109/210720-euco-finalconclusions-en.pdf, accessed August 03, 2020.

${ }^{22}$ For further development, see European Commission, Communication from the Commission to the European Parliament, the Council, the European Economic and Social Committee and the Committee of the Regions Powering a climate-neutral economy: An EU Strategy for Energy System Integration, Brussels, 8.7.2020 COM(2020) 299 final.

${ }^{23}$ Information available at: https:/ / eur-lex.europa.eu/legal-content/EN/TXT/?qid=1594897267722\&ur$\mathrm{i}=$ CELEX\%3A52020DC0301, accessed August 03, 2020.
} 
established leadership in renewable energy; a regional approach to system operation and infrastructure planning; liberalised energy markets; and excellence in energy innovation and digitalisation". ${ }^{24}$

The logic is simple: the COVID-19 crisis brings the lesson that efforts to keep the fundamental values of the EU's citizens protected must be more cohesive than ever. The problems to be faced are numerous and immediate. But what may be able to make a difference in, even if the deadlines for achieving the Green Deal goals are postponed ${ }^{25}$ or readjusted, ${ }^{26}$ is the Union showing the capacity to allow long-term goals, towards a sustainable and fair society, to direct necessary actions to overcome short-term emergencies in a unique and unprecedented opportunity by making the Green Deal a key component of the reconstruction of European economies.

Therefore, the EU's greatest challenge is to have the same dedication, at least, that it had to decrease the speed of contagion of COVID-19, by making efforts to lower the growth curve of the spread of the disease, to reduce the curve of unrestrained growth based on old polluting technologies in order not to reach - worse, exceed - the limits of the planet's resources in a way that has no return.

Is this a distant prospect to be reached? Not necessarily. Nevertheless, we must understand beforehand how the EU achieved this ambitious and unprecedented postpandemic recovery pact. What pathway does the EU take, in a joint action of all Member States leaders and European institutions, to provide citizens and businesses with a long-term opportunity to recover in an ecological and sustainable manner? Evidently, the observance of solidarity and cooperation, not only from civil society, but amongst Member States themselves was paramount to achieving firm plans for a most needed post-pandemic economic recovery.

\section{Solidarity and responsibility in the European Union}

Our intention, in this brief analysis, is not to unravel the origins and sociological concepts around the word solidarity (neither solidarity as a principle of law). What would force us to an in-depth juridical analysis to capture the link between what Solidarity represents, as an axiom, and how it relates to responsibility and resilience in the EU's context.

Recent events have already put in question the European Project: the immigration crisis of 2015, the economic crisis of 2008. Today, amidst the COVID-19 crisis, which impacted not only Europe, but the whole world has seen once again, the process of European integration being questioned, under the banner of what is in its essence: Solidarity. That is to say that the initial reactions from Member States and European institutions, as the coronavirus crisis arose, did not reflect this essence. ${ }^{27}$ Instead, the reaction of a few governments was to embrace, once again, austerity as a value and to close its borders as a protective measure.

\footnotetext{
${ }^{24}$ Information available at: https://ec.europa.eu/energy/sites/ener/files/energy_system_integration_strategy_.pdf, accessed August 03, 2020.

${ }^{25}$ Information available at: https://www.euractiv.com/section/energy-environment/news/leakedfull-list-of-delayed-european-green-deal-initiatives/, accessed August 03, 2020.

${ }^{26} 30 \%$ of the total expenditure from the MFF and Next Generation EU will target climate-related projects. Expenses under the MFF and Next Generation EU will comply with the EU's objective of climate neutrality by 2050, the EU's 2030 climate targets and the Paris Agreement. Information available at: https: / eur-lex.europa.eu/legal-content/EN/TXT/?qid=1594897267722\&uri=CELEX\%3A52020DC0301, accessed August 03, 2020.

${ }^{27}$ Information available at: https://www.dw.com/en/coronavirus-eu-apologizes-to-italy-for-initialresponse/a-53142603 and https://www.bbc.com/news/world-europe-52311263.
} 
It's imperative to clarity that in its foundation, the European Integration Project was carved out of the idea of Solidarity, as the cornerstone of this political project, which is fundamentally linked to the idea of sincere cooperation ${ }^{28}$ amongst the European people and Member States.

In this way, Solidarity is an unquestionable presence in EU's legal landscape, as well as constitutionally established in some Member States. ${ }^{29}$ The EU's Treaties refer to Solidarity on numerous occasions, from strictly legal-normative categories, including the Union's values and objectives ('inter-generational solidarity"30 and "between Member States'), to particular policies in which the "principle" or "spirit" of Solidarity must be abided by. Such references occur in the Treaties' preambles, ${ }^{32}$ as well as in its values ${ }^{33}$ and objectives. ${ }^{34}$

The Charter of Fundamental Rights of The European Union (CFREU) adopts solidarity as the title of Chapter IV for provisions that includes, for instance, workers' rights, social security and social assistance and health care. However, the Treaties are emphatic about solidarity when it comes to how Member States and public organisms should behave to one another, but not as easily discernible in legal terms as a general principle of Solidarity ${ }^{35}$ and its limits and practical applications.

Give that neither the Treaty on European Union (TEU) nor the TFEU include a legal definition of Solidarity, ${ }^{36}$ but in such cases, talk about spirit of Solidarity, "the European integration process was, however, rapidly constitutionalised, especially after the entry into force of the Treaty of Rome ${ }^{37}$, and under the decisive contribution of the case-law of the Court of Justice of the European Union (CJEU)". ${ }^{38}$ On the Judgment Les Verts Case

\footnotetext{
${ }^{28}$ Article 3(4) TEU.

${ }^{29}$ Article 66, no. 2, d), Constitution of The Portuguese Republic. Also, article 45, no. 2, The Spanish Constitution, article 7 bis, The Belgian Constitution, article 2, Constitution of the Italian Republic.

${ }^{30}$ Article 3(3), TEU.

${ }^{31}$ Article 67(2), TFEU.

32 "Desiring to deepen the solidarity between their peoples while respecting their history, their culture and their traditions", Preamble of the Treaty on European Union. And "Conscious of its spiritual and moral heritage, the Union is founded on the indivisible, universal values of human dignity, freedom, equality and solidarity; it is based on the principles of democracy and the rule of law. It places the individual at the heart of its activities, by establishing the citizenship of the Union and by creating an area of freedom, security and justice", preamble of the Charter of Fundamental Rights of the European Union. And, finally, "Intending to confirm the solidarity which binds Europe and the overseas countries and desiring to ensure the development of their prosperity, in accordance with the principles of the Charter of the United Nations", Preamble of the Treaty on the Functioning of the European Union.

${ }^{33}$ Article 2, of the TEU.

${ }^{34}$ Article 3, of the TEU.

${ }^{35}$ Rita Lages, "The principle of solidarity and fair sharing of responsibilities between the Member States on EU common asylum policy. Commentary to the Judgment of the Court of Justice (Grand Chamber) of 6 September 2017, Slovak Republic and Hungary v. Council of The European Union”, E-Pública, v. 5, no. 1 (January 2018): 289.

${ }^{36}$ Irina Domurath, "The three dimensions of solidarity in the EU legal order: limits of the judicial and legal approach", Journal of European Integration, v. 35, no. 4 (2012): 460, DOI: 10.1080/07036337.2012.704630.

${ }^{37}$ It set up the European Economic Community (EEC). Information available at https://eur-lex. europa.eu/legal-content/EN/TXT/?uri=LEGISSUM\%3Axy0023, accessed August 03, 2020.

${ }^{38}$ Sophie Perez Fernandes, "Good administration 'around the track' of the Portuguese and the EU constitutional discourses - 'Winds, to entertain our minds '...?”, Unio - EU Law Journal, v. 3, no. 1 (2017): 94, https://revistas.uminho.pt/index.php/unio/article/view/322/332.
} 
294/83, 23 April 1986, ${ }^{39}$ the European integration process, the CJEU recognised and emphasized that there is a principle of Solidarity between Member States: "the European Economic Community is a Community based on the rule of law, inasmuch as neither its Member States nor its institutions can avoid a review of the question whether the measures adopted by them are in conformity with the basic constitutional charter, the Treaty". ${ }^{40}$

As well in recent precedent of the CJEU, on Judgment Commission v Poland ${ }^{41}$ Advocate-General Eleanor Sharpston, in her Opinion, highlighted "the Schuman Declaration of 9 May 1950 famously recognised that Europe will not be made all at once, or according to a single plan. It will be built through concrete achievements which first create a de facto solidarity". ${ }^{2}$ Moreover, that "it clear that the principle of solidarity necessarily sometimes implies accepting burden-sharing" 3 and "solidarity is the lifeblood of the European project. Through their participation in that project and their citizenship of European Union, Member States and their nationals have obligations as well as benefits, duties as well as rights. Sharing in the European 'demos' is not a matter of looking through the Treaties and the secondary legislation to see what one can claim. It also requires one to shoulder collective responsibilities and (yes) burdens to further the common good". ${ }^{44}$ Hence why the CJEU understands that from Solidarity begins the foundation for a responsibility of respect and mutual assistance between Member States and the EU and another one of obedience to EU law. Thus, there is a link between the Principle of Solidarity that is a legal principle, and the Principle of Sincere Cooperation.

In today's context, embroiled in a deep and broad social, economic, sanitary, and environmental crisis, it is demanded that the EU display Solidarity and social justice, upholding its principles and commitments particularly amongst its Member States. Moreover, in a Union of Law, ${ }^{45}$ it's imperative is a clear understanding in what constitutes the interactions between the EU Law and national legal bodies in relation to the socioeconomic integration of different societies within Member States. To this end, Habermas understands that Solidarity between strangers is possible, in that, in complex societies, the law can generate a basis of motivation sufficiently flexible to preserve individual's freedom but strong enough to allow citizens to self-regulate and rationally assess ethical values that guide both individual and collective actions. ${ }^{46}$

\footnotetext{
${ }^{39}$ Judgment CJUE Les Vert, 23 April 1986s, Case 294/83, recital 23. Information available at: https:// eur-lex.europa.eu/legal-content/EN/ALL/?uri=CELEX\%3A61983CJ0294\#, accessed August 03, 2020. ${ }^{40}$ Judgment CJUE Les Vert, recital 23.

${ }^{41}$ Judgment CJUE Commission v Poland, 2 April 2020, Cases C715/17, C718/17 and C719/17, recital 247. Information available at: http://curia.europa.eu/juris/document/document.jsf?text=\&doci$\mathrm{d}=224882$ \&pageIndex $=0 \&$ doclang $=$ en\&mode $=1 \mathrm{st} \&$ dir $=\& o c c=$ first\&part $=1 \& \mathrm{cid}=15138476$, accessed August 03, 2020.

${ }^{42}$ Commission v Poland, recital 247.

${ }^{43}$ Commission v Poland, recital 251.

${ }^{44}$ Commission v Poland, recital 253.

${ }^{45}$ According to Alessandra Silveira, “(...) the European Union creates rights and is bound by the law that it creates. (...) the European Union functions as a Union of law (alluding to the expression Rule of Law). This means that the exercise of the public power of the Union must be subject to law, just as the exercise of public power of the State is subject to law (the meaning of the term "rule of law" is no different). It cannot be otherwise because the Union holds public power" in Alessandra Silveira, Princípios de Direito da União Europeia Doutrina e Jurisprudência (Lisboa: Quid Juris Sociedade Editora, 2011), 28 (free translation).

${ }^{46}$ Jürgen Habermas, Faktizität und Geltung. Beitrage zur Diskurstheorie des Rechts und des demokratischen Rechtsstaats (Aufl. Frankfurt am Main: Suhrkamp Verlag, 1994), 57 et seq. apud Alton Barbieri Durão, "Habermas: a possibilidade da solidariedade através da justiça", Dissertatio Revista de Filosofia, v. 35 (2012): 101, https://periodicos.ufpel.edu.br/ojs2/index.php/dissertatio/article/view/8681/5726.
} 
Now, Solidarity between Member States is in the center of discussions when it comes to what the European Project means and proposes since its inception. However, this Solidarity is not only limited to the aforementioned concept, but it also has to be discussed amongst the European people and its nationals themselves. In other words, actions at EU level must be address their longevity and reach, under the guise of an adequate legal framework, to implement measures that strengthen solidarity, with a focus on fomenting long-term educational and communication programs.

In this manner, support to civil society and organization is necessary and their role in a robust European social infrastructure, aligned with successful and innovative actions in research projects, as well as an adequate legal framework that allows civil interventions that directly improve every European citizen's lives. ${ }^{47}$ In other words, Member States should present a national action plan aimed at preserving quality and continuity of essential social services relevant to a social market economy with new directions based on the European Green Deal: social housing, access to basic health care, digital literacy and education for all, as well as training for less qualified workers.

In this sense, we must not forget the link between Solidarity and Responsibility, whose importance is fundamental. There are several examples in Member States' legal frameworks, under the aforementioned perspective, such as the Collective Social Solidarity mechanism designed to protect unemployed workers. Such programs show the collective interested of public and private sectors in providing minimum subsistence conditions to unemployed workers temporarily, as a trade-off to keep them away from unlawful activities during their hardship - as it is a requirement to benefit from these programs - in hopes that those workers are reinserted in the job market and become taxpayers once again. That is what one calls 'active solidarity', because it implies that the beneficiaries measure the meaning of their responsibility. ${ }^{48}$

Another mechanism that can improve the notion that only through Solidarity and Responsibility between Member States is how the European Project persists is by guaranteeing high standards of democracy and freedom, which have been fortunately achieved so far. Each citizen performs two roles: that of a citizen of their own country and that of a citizen of the EU. As European citizens realise that European decisions deeply affect their livelihoods, the more they will feel engaged in a European policy that also calls for cross-border collective sacrifices to be shared.

To this end, the EU updated the rules on the European Citizens' Initiative ${ }^{49}$ that those rules began to be applied from January 2020. ${ }^{50}$ The European Citizens' Initiative ensures "the Union's citizens ('citizens') are granted the right to approach the Commission directly with a request inviting it to submit a proposal for a legal act of the Union for the purpose of implementing the Treaties". ${ }^{51}$ The new rules aim to bring citizens closer to the Eu with requests to EU

\footnotetext{
${ }^{47}$ For further development, see The European Economic and Social Committee (EESC) that "is an EU advisory body comprising representatives of workers' and employers' organisations and other interest groups. It issues opinions on EU issues to the European Commission, the Council of the EU and the European Parliament, thus acting as a bridge between the EU's decision-making institutions and EU citizens. Information available at: https:/ / europa.eu/european-union/about-eu/institutionsbodies/european-economic-social-committee_en\#overview and https://www.eesc.europa.eu/en/ initiatives/ civil-society-against-covid-19.

${ }^{48}$ Jérôme Vignon, "Solidarity and responsibility in the European Union", Policy Brief Notre Europe, no. 26 (2011), https://institutdelors.eu/wp-content/uploads/2018/01/bref27_jvignon_en.pdf.

${ }^{49}$ Article 11(4) TEU and article 24 TFEU.

${ }^{50}$ Information available at: https://www.consilium.europa.eu/en/press/press-releases/2019/04/09/ updated-rules-on-the-european-citizens-initiative-adopted/, accessed August 15, 2020.

${ }^{51}$ For further development, see Regulation "Eu” 2019/788 of the European Parliament and of the
} 
decision-makers being made easier. Under these rules, changes such as: signatures can be collected through a central online system, initiatives can be signed by EU citizens whose age entitles them to vote in elections to the European Parliament, and the Member States will be able to set the minimum age at 16 years and are encouraged to consider doing this, in accordance with their national laws, allowing young people to participate in the initiatives.

It is important to remember that during the COVID-19 pandemic, the European Parliament and the Council of the European Union, in accordance with the principle of proportionality, "extended the period for the collection of statements of support by six months, covering the period from 11 March 2020, (...)"52 "for the achievement of the basic objective of preserving the efficacy of the European citizens' initiative instrument during the COVID-19 pandemic to lay down temporary measures concerning the time-limits for the collection, the verification and the examination stages ${ }^{\prime 53}$ provided for in Regulation (EU) 2019/788. ${ }^{54}$

As a result, in a context where the EU is claiming to be based on a set of values, the only way the European Project can endure, in a scenario where there are different economic development stages amongst Member States, is through cooperation in a democratically organised and shared responsibility structure. Therefore, "improving lives and having a robust civil society infrastructure ought to be selfevident and incontestable aspects of the European Union's continued objectives. Capturing the strength and potential of solidarity is an immense opportunity for the EU's own renewal, especially". 55 The more the national populations became aware and the media made them aware of the profound influence that EU decisions have on their daily lives, the higher their interest is likely to be in exercising their democratic rights as citizens of the Union.

\section{Closing remarks}

EU Solidarity is alive. The urgency in overcoming the Coronavirus crisis is another step in European integration that will help restore and strengthen the notion that Shared Responsibility is paramount to a long-term sense of Solidarity. From this perspective, Article 4 (3), TEU, must be put into practice "Pursuant to the principle of sincere cooperation, the Union and the Member States shall, in full mutual respect, assist each other in carrying out tasks which flow from the Treaties".

In this regard, it implies and justifies the existence of mutual trust between Member States. Values must be upheld, because it is the only way that EU law will be

Council on the European citizens' initiative, available at: https://eur-lex.europa.eu/legal-content/ PT-EN/TXT/?uri=CELEX:32019R0788\&from=PT. Also, there is the Regulation (EU) 2019/1799 of 22 October 2019 laying down technical specifications for individual online collection systems pursuant to Regulation (EU) 2019/788 of the European Parliament and of the Council on the European citizens' initiative. Information available at https://eur-lex.europa.eu/legal-content/PTEN/TXT/?uri=CELEX:32019R0788\&from=PT, accessed August 15, 2020.

${ }^{52}$ Regulation (EU) 2020/1042 of the European Parliament and of the Council of 15 July 2020, recital (6), laying down temporary measures concerning the time limits for the collection, the verification and the examination stages provided for in Regulation (EU) 2019/788 on the European citizens' initiative in view of the COVID-19 outbreak. Information available at: https://eur-lex.europa.eu/ legal-content/PT-EN/TXT/?uri=CELEX:32019R0788\&from=PT, accessed August 15, 2020.

${ }^{53}$ Regulation (EU) 2020/1042, recital (17).

${ }^{54}$ Information available at: https:/ / eur-lex.europa.eu/legal-content/PT-EN/TXT/?uri=CELEX:32019R0788\&from=PT, accessed August 15, 2020.

${ }^{55}$ European Commission, Solidarity in Europe - Alive and Active (Luxembourg: Publications Office of the European Union, 2018), 14, https://ec.europa.eu/research/social-sciences/pdf/policy_reviews/ solidarity_in_europe.pdf. 
respected and implemented as a reflection of the Union's mission and objectives, even if it's opposed to national interests at times, but through mutual loyalty the effectiveness of the EU's legal system will be guaranteed.

It's important to clarify that an epidemiological phenomenon such as COVID-19 and so many others in recent years (MERS, H1N1) are part of a larger crisis, the environmental crisis, as they are likely related to how humans are interacting with their surroundings and various animal species. In this way, "changes in mean climatic conditions and climate variability also can affect human health via indirect pathways, particularly via changes in biological and ecological processes that infuence infectious disease transmission and food yields" Moreover, "in addition to land-use changes, there is a host of indirect links between infectious disease and environmental conditions that are mediated through changes in ecosystems resulting from buman activities $^{57}$ ". Based on this understanding, the pathway may be hard, because we do not know what can result from the complex interactions between human activity and climate change and the conditions for infectious diseases caused by microorganisms.

This approach compels us to understand the importance of implementing the Green Deal with responsibility and resilience, by consciously using the Recovery Plan's investments on each Member State, which is not only an instrument for financial resource redistribution, but clearly a political plan with a joint strategy, as to enable an economic recovery that allows for the integration of new policies in key sectors aligned with EU governance levels aiming to build a climate-neutral, green, fair and social Europe.

Thus, Solidarity and Responsibility as a concept and practice must journey together, as to generate long-term Solidarity in the EU, built around common objectives, calls for a joint political and juridical effort in defining which active Solidarity areas allow for what kind of reciprocity can be achieved by countries whose needs and capabilities are frequently different. The Green Deal is a great path.

The EU, in this way, cannot miss the opportunity to reaffirm that the European Project is still alive, for it is realised through measures that reinvigorate the meaning of Solidarity and Responsibility, so it will be prepared to face present and future challenges, such as climate changes, and assume the role of global leadership, since exceptional times demands decisive actions. Unequivocally, the integrity of the EU depends on it.

\footnotetext{
${ }^{56}$ J. A. Patz et. al., "Climate change and infectious diseases", Climate change and buman health: risks and responses (2003): 103, https://www.who.int/globalchange/publications/climatechangechap6.pdf?ua=1.

${ }^{57}$ Patz et. al., "Climate change and infectious diseases", 124.
} 